\title{
Nutritional Evaluation of Okra Pod and Mother Soil as Influenced by Sawdust Ash, Ammonium nitrate and NPK
}

\author{
Abdulraheem Mukhtar Iderawumi ${ }^{1{ }^{1 *},}$ Charles Eneminyene Friday ${ }^{2}$, Omogoye Adewale Mubo $^{1}$ \\ ${ }^{1}$ Department of Agricultural Education, The College of Education, Nigeria \\ ${ }^{2}$ Nigeria Institute for Oil Palm Research, Benin City, Edo State, Nigeria
}

Copyright $\mathrm{O} 2017$ by authors, all rights reserved. Authors agree that this article remains permanently open access under the terms of the Creative Commons Attribution License 4.0 International License

\begin{abstract}
The demand for okra usually exceeds what is being produced in Nigeria. Poor soil fertility due to soil degradation partly accounts for the low yield of the crop. Inorganic and organic fertilizers have been found to effectively replenish soil nutrients' losses. Hence this study aimed at carrying out the nutritional evaluation of okra pod and mother soil as influenced by sawdust ash (SDA) on soil properties and okra pod nutrients when used alone or combined with Ammonium nitrate or NPK. There were ten treatments replicated three times in a Randomized Complete Block Design. Treatments were applied three weeks after planting by ring method with NPK or Ammonium nitrate and SDA mixed. The test soil indicated that it was marginal in organic matter, inadequate in available $\mathrm{P}$ and slightly acidic. Sole SDA increase the soil P relative to control and sole use of Ammonium nitrate or NPK in 2016. SDA and its combination with NPK or Ammonium nitrate increased soil $\mathrm{N}$, available $\mathrm{P}$, exchangeable $\mathrm{K}, \mathrm{Ca}$, and $\mathrm{Mg}$ in 2015. SDA alone with its varying combination with Ammonium nitrate and NPK increase the leaf $\mathrm{N}, \mathrm{K}, \mathrm{Ca}, \mathrm{P}, \mathrm{Mg}$ contents. Addition of SDA to chemical fertilizer such as NPK or Ammonium nitrate increases the soil and plant nutrients and also had liming effects.
\end{abstract}

Keywords Okra, Pod, Soil, Sawdust Ash, Ammonium nitrate, NPK

\section{Introduction}

In many developing countries, farmers have limited financial resources and can rarely afford to purchase sufficient mineral fertilizer. The use of synthetic fertilizers is beyond the reach of peasant farmers due to their cost and scarcity. Crops have become so expensive to grow that nutrient deficiencies should not be allowed to limit the yields. Common crop management practices such as continuous cropping and reduced fallow periods, can hardly support sustainable cropping. The need therefore, arises for production practices that will ensure high yield.

Okra (Abelmoschus esculentus (L.) Moench) is a popular vegetable grown for its pods and leaves. It has been found that continuous use of nitrogen fertilizer increases soil acidity and reduces nutrient uptake and yield of okra [7, 8]. Okra cultivation and production has been widely practiced because of its importance to the economic development and can be found in almost every market in Africa. Varieties vary by plant height, size of fruit, colour, early or late maturing etc., namely white velvet, green velvet, long fruit, lady finger, dwarf green fruits [35].

Okra is a native of tropical parts of Africa but now being widely grown and spread throughout the tropics, sub-tropics and even warmer temperate areas. Okra is an erect, coarse annual crop growing up to between $1 \mathrm{~m}$ and $2 \mathrm{~m}$, resembling other mallows. The leaves are large, alternate, cordate and divided into 3-7 lobes with toothed margins; reaching about $30 \mathrm{~cm}$ in length and generally hairy [1]. Okra requires a moderate rainfall of $80-100 \mathrm{~cm}$ well distributed to produce its young edible fruits over a relatively long period. An average temperature of $20^{\circ} \mathrm{C}$ to $30^{\circ} \mathrm{C}$ is considered optimum for growth, flowering and fruiting [3]. Soil type does not appear to influence growth or development to any marked extent as a wide range of soil types has been found suitable for is growth. In Nigeria, production is mainly during the warm season, although it can be grown all the year round depending on the varieties [2].

Okra plays an important role in the human diet by supplying carbohydrate, protein, fats, minerals and vitamins that are usually deficient in some staple foods [2]. The nutritional importance of okra pod has re-awakened interest in bringing the crop into commercial production [21]. Okra has the advantage of being agronomically suitable for intercropping with most arable crops [19]. With respect to climatic requirements, okra is noted for being tolerant in many parts of Nigeria where the climatic conditions are not suitable for the cultivation of other vegetable crops [13]. Okra is usually available fresh year-round in the South 
western part of Nigeria and from May to October in many other areas. Okra has both domestic and industrial applications [3, 32].

Okra contains $86 \%$ of water, $2.2 \%$ of protein, $10 \%$ of carbohydrate, $0.2 \%$ of fat and vitamins $\mathrm{A}, \mathrm{B}$ and C. [15] documented that okra is consumed throughout Nigeria. Okra is in high demand particularly in rural villages and in the drier regions where a slimy vegetable is needed as an accompaniment to the often coarse and staple food such as millet, garri and others. In Nigeria, okra is grown for its fruits which are used in the preparation of different kinds of soups with or without other condiments [18].

[1] stated that okra contains high amount of protein, oil, vitamins and minerals which has given it high markets demand that calls for good and better varieties to meet the population demand. The role of organic wastes as sources of plant nutrients and as amendment to improve soil quality parameters cannot be overemphasized. [31] reported the role of organic manure for sustaining the fertility of the soil to enhance the performance of vegetables and for binding the fine soil particles together, thereby preventing erosion and leaching in agricultural soil.

Ash derived from burnt plant residue is a source of plant nutrients $[4 ; 27]$ which can be used alone or in combination with N-rich chemical fertilizer or organic manure such as that of goat and poultry. The majority of the Southern Sudan recognizes that accumulations of wood ash provide valuable sites for cultivating ecologically specialized plants. Soils in the area are largely acidic, so K. can become a limiting factor. With no synthetic fertilizer available, wood ash has a clear and significant effect on the growth and yield of many crops [33]. Ash is composed of many major and minor elements needed by the tree for plant growth. Since most of these elements are extracted from the soil and atmosphere during the tree's growth cycle, they are elements that are common in our environment and are also essential elements in the production of crops and forages.

Wood ash contains nutrients which are readily available to plants and this raises the possibility of using it as fertilizer. [17] in the South West Nigeria found positive response of yield and nutrients contents of amaranthus and okra to application of wood ash treatments. In another study [26] found that application of 2, 4, 6, and 8 $\mathrm{t} / \mathrm{ha}$ wood ash treatments increased okra fruit count and weight, soil organic matter, $\mathrm{N}, \mathrm{P}, \mathrm{K}, \mathrm{Ca}$ and $\mathrm{Mg}$ contents and leaf $\mathrm{N}, \mathrm{P}$, and $\mathrm{K}$ contents. Another investigation was carried out [28] to investigate the effectiveness of wood ash fertilizer on maize grown under a humid tropical condition. Wood ash was applied at $0,2,4,6$ and 8 tha $^{-1}$ to maize crops. Wood ash increased soil organic matter content $\mathrm{pH}, \mathrm{N}, \mathrm{P}, \mathrm{K} \mathrm{Ca}$ and $\mathrm{Mg}$ contents. Wood ash treatments increased maize plant height, ear and grain weight significantly.

There is scarcity of published work on integrated use of wood ash and chemical fertilizers in improving the yield of crops and soil fertility [4]. The integrated application of organic and inorganic nutrient sources rather than total dependence on any of the sources is expected to ensure reduction in expenditure on chemical fertilizers, a more balanced plant nutrition and control of soil acidity. Since sawdust ash is a waste which poses environmental concern, its combined use with chemical fertilizer in crop production will assist in environmental sanitation

Due to increasing number of saw milling industries in Nigeria, sawdust is being daily generated and burnt. There is urgent need to study the use of sawdust ash waste for soil improvement and as fertilizer and liming material. Hence, the objective of this study is to evaluate the effect of combined application of Sawdust ash and its combined application with Ammonium nitrate and NPK fertilizer on the growth and pod yield of okra plant nutrients composition and okra nutritional quality.

\section{Materials and Methods}

Field experiments were carried out at the Teaching and Research Farm of The College of Education, Lanlate (formerly Emmanuel Alayande College of Education, Oyo, Lanlate Campus), Southwest, Nigeria in 2015 and 2016 cropping seasons to study the effects of Sawdust Ash (SDA) on soil and okra pod nutrients composition when used alone or combined with Ammonium nitrate and NPK. Lanlate lies between latitude $7^{0} 30^{\prime} \mathrm{N}$ and Longitude $3^{0} 52^{\prime} \mathrm{E}$ in the tropical rainforest belt $f$ Nigeria. There are two rainy seasons; one from April to July (early season) and the other from mid-August to November (late season). Annual average minimum and maximum temperatures are $24.80^{\circ} \mathrm{C}$ and $28.10^{\circ} \mathrm{C}$ respectively. The mean relative humidity is about $75 \%$. The soil at the site is classified as an alfisol (Oxic tropuldalf) according to [6]. There were ten treatments replicated three times in a Randomized Complete Block Design. Treatments were applied three weeks after planting by ring method with NPK or Ammonium nitrate and SDA mixed.

Surface $(0-15 \mathrm{~cm})$ soil samples were taken before the commencement of the experiments (initial soil analysis) and twelve weeks after treatment application. Immediately after collection of surface soil samples using steel auger, samples were bulked for each year, air-dried and allowed to pass through $2 \mathrm{~mm}$ sieve for analysis as outlined by procedures of [34]. Total $\mathrm{N}$ was determined by Kjedahl method, P by molybdenum blue colorimetry while $\mathrm{K}, \mathrm{Ca}$ and $\mathrm{Mg}$ extracted with ammonium acetate $\mathrm{pH} 7.0$ extractant after which the exchangeable $\mathrm{K}$ was evaluated using flame photometer while $\mathrm{Ca}$ and $\mathrm{Mg}$ were evaluated by EDTA titration. Soil $\mathrm{pH}$ in water was determined using $\mathrm{pH}$ meter in 1: 2 soil water ratio medium. Organic carbon and organic matter was determined using Walkley Black dicromate method (1934) as modified by [22].

Leaf samples collected at 10 weeks after treatment application in each plot, were oven dried at $70^{\circ} \mathrm{C}$ for 24 
hours. Ground samples of the leaves were analysed for N using micro Kjeldahl digestion method. Moreover, samples were digested with nitric - perchloric acid mixture for determination of $\mathrm{P}, \mathrm{K}, \mathrm{Ca}$ and $\mathrm{Mg}$ (IITA, 1979). The $\mathrm{P}$ was determined using molybdenum blue colorimetry, $\mathrm{K}$ by flame photometer, while $\mathrm{Ca}$ and $\mathrm{Mg}$ by EDTA titration [20]. Data were analysed using Analysis of Variance (ANOVA) to determine the effects of treatments on the parameters measured. Duncan Multiple Range Test was used to compare the treatment means.

\section{Results}

Analytical data of pre-cropping surface soil at the site of experiment are shown in table 1 . The test soil was marginal in organic matter (OM), adequate in Nitrogen, Calcuim, Magnesium and Potassium but inadequate in Phosphorus and slightly acidic [11]. Therefore the soil requires application of fertilizing amendment that will particularly supply P for enhancing okra.
Table 1. Initial soil analysis of experimental site at Lanlate

\begin{tabular}{ccc}
\hline Properties & \multicolumn{2}{c}{ Values } \\
& 2015 & 2016 \\
\hline $\mathrm{pH}\left(\mathrm{H}_{2} \mathrm{O}\right)$ & 6.50 & 6.60 \\
Organic Matter $(\mathrm{g} / \mathrm{kg})$ & 28.0 & 26.9 \\
Total nitrogen $(\mathrm{N}) \mathrm{g} / \mathrm{kg}$ & 3.20 & 2.80 \\
Available phosphorous $(\mathrm{P})(\mathrm{mg} / \mathrm{kg})$ & 8.80 & 9.10 \\
Exchangeable calcium $(\mathrm{cmol} / \mathrm{kg})$ & 7.31 & 6.35 \\
Exchangeable magnesium $(\mathrm{Mg})(\mathrm{cmol} / \mathrm{kg})$ & 2.50 & 2.40 \\
Exchangeable sodium $(\mathrm{Na})(\mathrm{cmol} / \mathrm{kg})$ & 1.60 & 1.70 \\
Exchangeable potassium $(\mathrm{K})(\mathrm{cmol} / \mathrm{kg})$ & 0.30 & 0.35 \\
Sandy $(\mathrm{g} / \mathrm{kg})$ & 878.0 & 875.0 \\
Silt $(\mathrm{g} / \mathrm{kg})$ & 54.0 & 56.0 \\
Clay $(\mathrm{g} / \mathrm{kg})$ & 68.0 & 69.0 \\
Texture & loamy sand \\
\hline
\end{tabular}

Table 2. Effects of Saw dust, Ammonium nitrate, NPK Fertilizers and their combinations on Soil Nutrient Composition in Lanlate (2015)

\begin{tabular}{|c|c|c|c|c|c|c|c|}
\hline \multirow{3}{*}{$\begin{array}{c}\text { Experiment } \\
\text { Control }\end{array}$} & $\mathrm{pH}$ & $\mathrm{OM}$ & $\mathrm{N}$ & \multirow{3}{*}{$\begin{array}{c}\mathrm{P} \\
(\mathrm{mg} / \mathrm{kg}) \\
11.02 \mathrm{~h}\end{array}$} & $\mathrm{~K}$ & $\mathrm{Ca}$ & $\mathrm{Mg}$ \\
\hline & & \multicolumn{2}{|c|}{$(\%)$} & & \multicolumn{3}{|c|}{$(\mathrm{cmol} / \mathrm{kg})$} \\
\hline & $5.74 \mathrm{~b}$ & $0.46 \mathrm{f}$ & $0.11 \mathrm{~d}$ & & $0.15 \mathrm{c}$ & $0.43 \mathrm{f}$ & $0.47 \mathrm{e}$ \\
\hline $100 \% \mathrm{SDA}$ & $5.92 \mathrm{a}$ & $0.27 \mathrm{~g}$ & $0.11 \mathrm{~d}$ & $13.48 \mathrm{~g}$ & $0.30 \mathrm{a}$ & $5.47 \mathrm{~b}$ & $3.63 \mathrm{a}$ \\
\hline $100 \%$ NPK & $5.82 \mathrm{ab}$ & $1.59 \mathrm{c}$ & $0.23 \mathrm{a}$ & $38.54 \mathrm{a}$ & $0.26 \mathrm{~b}$ & $0.42 \mathrm{f}$ & $0.16 \mathrm{f}$ \\
\hline $25 \% \mathrm{SDA}+75 \% \mathrm{NPK}$ & $5.83 \mathrm{ab}$ & $3.80 \mathrm{a}$ & $0.17 \mathrm{~b}$ & $35.47 \mathrm{~b}$ & $0.24 \mathrm{~b}$ & $7.07 \mathrm{a}$ & $1.65 \mathrm{bc}$ \\
\hline $50 \% \mathrm{SDA}+50 \% \mathrm{NPK}$ & $5.96 \mathrm{a}$ & $2.68 \mathrm{~b}$ & $0.14 \mathrm{~cd}$ & $32.38 \mathrm{c}$ & $0.32 \mathrm{a}$ & $5.56 \mathrm{~b}$ & $1.44 \mathrm{~cd}$ \\
\hline $75 \% \mathrm{SDA}+25 \% \mathrm{NPK}$ & $5.99 \mathrm{a}$ & $2.38 \mathrm{~b}$ & $0.12 \mathrm{~d}$ & $28.48 \mathrm{~d}$ & $0.38 \mathrm{a}$ & $3.73 \mathrm{~d}$ & $1.57 \mathrm{c}$ \\
\hline $100 \% \mathrm{AN}$ & $5.72 \mathrm{~b}$ & $0.64 \mathrm{ef}$ & $0.15 \mathrm{c}$ & $10.66 \mathrm{~h}$ & $0.14 \mathrm{c}$ & $2.10 \mathrm{e}$ & $1.03 \mathrm{~d}$ \\
\hline $25 \% \mathrm{SDA}+75 \% \mathrm{AN}$ & $5.83 \mathrm{ab}$ & $0.89 \mathrm{~d}$ & $0.12 \mathrm{~d}$ & $20.51 \mathrm{e}$ & $0.23 b$ & $4.80 \mathrm{c}$ & $2.00 \mathrm{~b}$ \\
\hline $50 \% \mathrm{SDA}+50 \% \mathrm{AN}$ & $5.85 \mathrm{ab}$ & $0.79 \mathrm{e}$ & $0.17 \mathrm{~b}$ & $15.61 \mathrm{fg}$ & $0.24 \mathrm{~b}$ & $4.93 \mathrm{c}$ & $1.20 \mathrm{~d}$ \\
\hline $75 \% \mathrm{SDA}+25 \% \mathrm{AN}$ & $5.83 \mathrm{ab}$ & $0.89 \mathrm{~d}$ & $0.17 \mathrm{~b}$ & $17.2 \mathrm{f}$ & $0.24 \mathrm{~b}$ & $4.80 \mathrm{c}$ & $2.00 \mathrm{~b}$ \\
\hline
\end{tabular}

Means in the same columns not followed by same letters are significantly different at $5 \%$ level of significance by Duncan's Multiple Range Test (DMRT). Keys : AN - Ammonium nitrate, NPK - Nitrogen Phosphorus Potassium, SDA - Sawdust Ash

Table 3. Effects of Saw dust, Ammonium nitrate, NPK Fertilizers and their combinations on Soil Nutrient Composition in Lanlate (2016)

\begin{tabular}{|c|c|c|c|c|c|c|c|c|}
\hline Experiment & $\mathrm{pH}$ & $\mathrm{OM}$ & $\mathrm{N}$ & $\begin{array}{c}\mathrm{P} \\
(\mathrm{mg} / \mathrm{kg})\end{array}$ & $\mathrm{K}$ & \multicolumn{2}{c|}{$\begin{array}{c}\mathrm{Ca} \\
(\mathrm{cmol} / \mathrm{kg})\end{array}$} \\
\hline Control & $5.79 \mathrm{~b}$ & $0.75 \mathrm{e}$ & $0.11 \mathrm{~b}$ & $7.21 \mathrm{~g}$ & $0.17 \mathrm{bc}$ & $1.77 \mathrm{~d}$ & 0.67 \\
\hline $100 \%$ SDA & $6.00 \mathrm{a}$ & $0.87 \mathrm{e}$ & $0.10 \mathrm{~b}$ & $43.56 \mathrm{~b}$ & $0.19 \mathrm{bc}$ & $3.23 \mathrm{bc}$ & $1.37 \mathrm{a}$ \\
\hline $100 \% \mathrm{NPK}$ & $6.15 \mathrm{a}$ & $1.78 \mathrm{c}$ & $0.34 \mathrm{a}$ & $29.21 \mathrm{~d}$ & $0.35 \mathrm{a}$ & $0.50 \mathrm{e}$ & 0.18 \\
\hline $25 \% \mathrm{SDA}+75 \% \mathrm{NPK}$ & $5.90 \mathrm{ab}$ & $3.34 \mathrm{a}$ & $0.16 \mathrm{~b}$ & $33.67 \mathrm{c}$ & $0.20 \mathrm{~b}$ & $6.27 \mathrm{a}$ & $1.37 \mathrm{a}$ \\
$50 \% \mathrm{SDA}+50 \% \mathrm{NPK}$ & $6.13 \mathrm{a}$ & $2.48 \mathrm{~b}$ & $0.14 \mathrm{~b}$ & $30.33 \mathrm{~cd}$ & $0.25 \mathrm{~b}$ & $5.10 \mathrm{ab}$ & $1.30 \mathrm{a}$ \\
\hline $75 \%$ SDA + 25\% NPK & $6.00 \mathrm{a}$ & $2.24 \mathrm{~b}$ & $0.12 \mathrm{~b}$ & $26.18 \mathrm{e}$ & $0.32 \mathrm{a}$ & $3.63 \mathrm{bc}$ & $1.35 \mathrm{a}$ \\
\hline $100 \%$ AN & $5.72 \mathrm{~b}$ & $0.67 \mathrm{e}$ & 0.10 & $17.71 \mathrm{f}$ & $0.19 \mathrm{bc}$ & $2.60 \mathrm{c}$ & 1.03 \\
$25 \% \mathrm{SDA}+75 \% \mathrm{AN}$ & $5.90 \mathrm{ab}$ & $1.10 \mathrm{~d}$ & $0.16 \mathrm{~b}$ & $51.93 \mathrm{a}$ & $0.19 \mathrm{bc}$ & $3.20 \mathrm{bc}$ & $1.33 \mathrm{a}$ \\
\hline $50 \% \mathrm{SDA}+50 \% \mathrm{AN}$ & $5.88 \mathrm{~b}$ & $1.66 \mathrm{c}$ & $0.12 \mathrm{~b}$ & $49.26 \mathrm{ab}$ & $0.11 \mathrm{c}$ & $2.33 \mathrm{c}$ & $0.97 \mathrm{c}$ \\
\hline $75 \% \mathrm{SDA}+25 \% \mathrm{AN}$ & $5.86 \mathrm{~b}$ & $1.23 \mathrm{~d}$ & $0.11 \mathrm{~b}$ & $33.60 \mathrm{c}$ & $0.18 \mathrm{bc}$ & $4.60 \mathrm{~b}$ & $1.17 \mathrm{~b}$ \\
\hline
\end{tabular}

Means in the same columns not followed by same letters are significantly different at $5 \%$ level of significance by Duncan's Multiple Range Test (DMRT). Keys : AN - Ammonium nitrate, NPK - Nitrogen Phosphorus Potassium, SDA - Sawdust Ash 
Table 4. Effects of Saw dust, Ammonium nitrate, NPK Fertilizers and their combinations on Okra Pod Nutrient Composition in Lanlate (2015)

\begin{tabular}{|c|c|c|c|c|c|}
\hline \multirow{2}{*}{ Experiment } & $\mathrm{N}$ & $\mathrm{P}$ & K & $\mathrm{Ca}$ & $\mathrm{Mg}$ \\
\hline & \multicolumn{5}{|c|}{$(\%)$} \\
\hline Control & $1.90 \mathrm{~b}$ & $0.03 \mathrm{e}$ & $0.46 \mathrm{c}$ & $0.36 \mathrm{c}$ & 0.05 \\
\hline $100 \%$ SDA & $3.20 \mathrm{a}$ & $1.20 \mathrm{~b}$ & $1.06 \mathrm{a}$ & $0.75 b$ & 0.22 \\
\hline $100 \% \mathrm{NPK}$ & $1.24 \mathrm{c}$ & $0.30 \mathrm{~d}$ & $0.79 b$ & $1.02 \mathrm{a}$ & 0.18 \\
\hline $25 \% \mathrm{SDA}+75 \% \mathrm{NPK}$ & $1.38 \mathrm{ab}$ & $0.28 \mathrm{~d}$ & $0.73 b$ & $0.83 \mathrm{ab}$ & 0.12 \\
\hline $50 \% \mathrm{SDA}+50 \% \mathrm{NPK}$ & $1.41 \mathrm{ab}$ & $0.28 \mathrm{~d}$ & $0.75 b$ & $0.99 \mathrm{a}$ & 0.13 \\
\hline $75 \% \mathrm{SDA}+25 \% \mathrm{NPK}$ & $1.31 \mathrm{ab}$ & $0.31 \mathrm{~d}$ & $0.78 \mathrm{~b}$ & $1.14 \mathrm{a}$ & 0.13 \\
\hline $100 \% \mathrm{AN}$ & $2.44 \mathrm{ab}$ & $1.86 \mathrm{a}$ & $0.40 \mathrm{c}$ & 0.64 & 0.14 \\
\hline $25 \% \mathrm{SDA}+75 \% \mathrm{AN}$ & $1.93 \mathrm{~b}$ & $0.89 \mathrm{c}$ & $0.34 \mathrm{c}$ & $0.77 \mathrm{~b}$ & 0.11 \\
\hline $50 \% \mathrm{SDA}+50 \% \mathrm{AN}$ & $2.38 \mathrm{ab}$ & $1.09 \mathrm{~b}$ & $0.34 \mathrm{c}$ & $0.92 \mathrm{a}$ & 0.19 \\
\hline $75 \% \mathrm{SDA}+25 \% \mathrm{AN}$ & $2.56 \mathrm{ab}$ & $1.25 \mathrm{~b}$ & $0.40 \mathrm{c}$ & $0.81 \mathrm{ab}$ & 0.16 \\
\hline
\end{tabular}

Means in the same columns not followed by same letters are significantly different at 5\% level of significance by Duncan's Multiple Range Test (DMRT). Keys : AN - Ammonium nitrate, NPK - Nitrogen Phosphorus Potassium, SDA - Sawdust Ash

Table 5. Effects of Saw dust, Ammonium nitrate, NPK Fertilizers and their combinations on Okra Pod Nutrient Composition in Lanlate (2016)

\begin{tabular}{|c|c|c|c|c|c|}
\hline \multirow{2}{*}{ Experiment } & $\mathrm{N}$ & $\mathrm{P}$ & K & $\mathrm{Ca}$ & $\mathrm{Mg}$ \\
\hline & \multicolumn{5}{|c|}{$(\%)$} \\
\hline Control & $1.92 \mathrm{~b}$ & $0.76 b$ & $2.97 \mathrm{~b}$ & $0.80 \mathrm{~b}$ & $1.74 \mathrm{~b}$ \\
\hline $100 \% \mathrm{SDA}$ & $2.47 \mathrm{ab}$ & $1.83 \mathrm{a}$ & $3.26 \mathrm{a}$ & $1.74 \mathrm{a}$ & $2.18 \mathrm{a}$ \\
\hline $100 \%$ NPK & $3.69 \mathrm{a}$ & $0.35 \mathrm{c}$ & $2.86 \mathrm{~b}$ & $0.37 \mathrm{c}$ & $0.13 \mathrm{c}$ \\
\hline $25 \% \mathrm{SDA}+75 \% \mathrm{NPK}$ & $1.26 \mathrm{c}$ & $0.29 \mathrm{c}$ & $0.70 \mathrm{c}$ & $1.11 \mathrm{~b}$ & $0.12 \mathrm{c}$ \\
\hline $50 \% \mathrm{SDA}+50 \% \mathrm{NPK}$ & $1.34 \mathrm{c}$ & $0.26 \mathrm{c}$ & $0.72 \mathrm{c}$ & $0.90 \mathrm{~b}$ & $0.11 \mathrm{c}$ \\
\hline $75 \% \mathrm{SDA}+25 \% \mathrm{NPK}$ & $1.31 \mathrm{c}$ & $0.22 \mathrm{c}$ & $0.70 \mathrm{c}$ & $0.84 \mathrm{~b}$ & $0.11 \mathrm{c}$ \\
\hline $100 \% \mathrm{AN}$ & $2.53 \mathrm{a}$ & $0.83 \mathrm{a}$ & $3.28 \mathrm{a}$ & $0.64 \mathrm{c}$ & $0.14 \mathrm{c}$ \\
\hline $25 \% \mathrm{SDA}+75 \% \mathrm{AN}$ & $2.53 \mathrm{a}$ & $0.87 \mathrm{a}$ & $0.33 \mathrm{~d}$ & $0.49 \mathrm{c}$ & $0.11 \mathrm{c}$ \\
\hline $50 \% \mathrm{SDA}+50 \% \mathrm{AN}$ & $2.29 \mathrm{ab}$ & $0.86 \mathrm{a}$ & $0.29 \mathrm{~d}$ & $0.87 b$ & $0.19 \mathrm{c}$ \\
\hline $75 \% \mathrm{SDA}+25 \% \mathrm{AN}$ & $2.59 \mathrm{a}$ & $0.87 \mathrm{a}$ & $0.29 \mathrm{~d}$ & $0.68 \mathrm{c}$ & $0.16 \mathrm{c}$ \\
\hline
\end{tabular}

Means in the same columns not followed by same letters are significantly different at 5\% level of significance by Duncan's Multiple Range Test (DMRT). Keys: AN - Ammonium nitrate, NPK - Nitrogen Phosphorus Potassium, SDA - Sawdust Ash

\section{Discussion}

The SDA, Ammonium nitrate and NPK and their combination increased soil $\mathrm{N}, \mathrm{P}, \mathrm{K}, \mathrm{Ca}$ and $\mathrm{Mg}$ significantly. The combinations also increase organic matter $(\mathrm{OM})$. The effect of ammonium nitrate in increasing the nutrients can be adduced to associated increase in OM (Table 2 and 3). The increase in soil nutrients due to application of SDA is constant with earlier findings $[4,16]$ and the fact that ash is an effective source of OM and micronutrients [31,2] for increasing crop performance [29]. Hence it is observed in this study that combination of SDA and Ammonium nitrate had higher values of soil N, P, K, Ca and Mg especially in 2015 due to nutrients supply from the two sources and the fact that SDA gave highest values of soil $\mathrm{K}, \mathrm{Ca}$ and $\mathrm{Mg}$ which thereby giving it liming effects. Organic fertilizers have beneficial effect on nutrient composition, structural aggregation, infiltration, microbial and other biological activities of the soil; this and with a host of others will subsequently improve okra production particularly in the tropics.

Aside from its liming effect, it was found in the present work that SDA significantly increased soil P, K, $\mathrm{Ca}$ and $\mathrm{Mg}$. this is consistent with analysis data given for the material which show that it contained macronutrients. Wood ash and other types of plant derived ashes were also found to increase organic matter, $\mathrm{N}, \mathrm{P}, \mathrm{K}, \mathrm{Ca}$ and $\mathrm{Mg}$ in soil which were made available for uptake of crops such as cocoa [14]. Field experiments carried out in South-West Nigeria have shown positive response of yield and nutrients contents of amaranthus and okra to application of wood ash as reported by [17]. Application of 2, 4, 6, 8 tons/ha ash increase okra pod and weight [27]. For the planting of pepper and other vegetables in Eastern Nigeria at household levels, the use of poultry droppings, cow dung, wood ash and composted residues for improving soil fertility has been adopted. Other studies [25, 12, 36; 24] carried out in parts of Africa found that plant derived ash increased P, K, $\mathrm{Ca}, \mathrm{Mg}$ status of soil, $\mathrm{pH}$ and yield of vegetables. Studies 
carried out earlier by the researcher in southwest Nigeria showed that sawdust ash and Ammonium nitrate fertilizer at $1.5 \mathrm{t} / \mathrm{ha} \mathrm{SDA}+180 \mathrm{~kg} / \mathrm{ha} U$ increased the grain yield of sorghum [5].

In terms of nutrients uptake, SDA alone or with combined with Ammonium nitrate or NPK was found to increase $\mathrm{P}, \mathrm{Ca}$ and $\mathrm{Mg}$ concentrations significantly in okra plant. Its combined use at $50 \%$ SDA $+50 \%$ AN and 50\% SDA $+50 \%$ NPK significantly increased plant $\mathrm{P}$ and $\mathrm{Ca}$. The latter combination also gave highest plant $\mathrm{N}$ and $\mathrm{P}$ among combined treatments. This affirms that SDA is a source of nutrients for crop uptake. [23, 9, 10].

\section{REFERENCES}

[1] Abdulraheem, M.I., Omogoye, A.M., Charles, E.F. (2017, May): "Application Effects of Pig Manure and NPK Fertilizer on Soil Chemical Properties and Okra Leaf Nutrient Contents". Paper presented at the $6^{\text {th }}$ International and $15^{\text {th }}$ National Conference on 'Dynamic Trends in Plant Science: Fostering Environment'. 9-11 ${ }^{\text {th }}$ May, 2017. Quetta, Pakistan.

[2] Abdulraheem, M.I. and Charles, E.F. (2016): Soil and Okra Pod Nutrients Composition as affected by Combined Application of Oil palm Bunch Ash, Ammonium nitrate and NPK. Paper presented at the $40^{\text {th }}$ Conference of the Soil Science Society of Nigeria held at University of Calabar, Calabar. $14^{\text {th }}-18^{\text {th }}$ March.

[3] Abdulraheem, M.I. and Ojeniyi, S.O. 2015. Combined Application of Ammonium nitrate and Sawdust Ash in Okra Production Effects on Yield and Nutrients Availability. Nigeria Journal of Soil Science. 25: 146 - 154

[4] Abdulraheem, M.I.; Ojeniyi, S.O and Charles, E.F. 2012. Integrated Application of Ammonium nitrate and Sawdust Ash: Effects on Soil Chemical Properties, Plant Nutrients and Sorghum Performance. International Organization of Scientific Research-Journal of Agriculture and Veterinary science (IOSR-JAVS), Volume 1, Issue 4 (Nov. - Dec. 2012), pp 38-41

[5] Abdulraheem, M.I. 2011. Effects of Ammonium nitrate and Sawdust Ash Manure on Soil Chemical Properties and Sorghum (Sorghum bicolor L. (moench) mill) Performance in Lanlate, Nigeria. A Research Project Submitted to the Department of Crop, Soil And Pest Management, Federal University of Technology, Akure in Partial Fulfilment of the Requirement for the Award of Post Graduate Diploma (PGD) in Crop, Soil and Pest Management.

[6] Adeputu, J. A., Adebayo, A.A., Aduayi, E.A. and Alofe, C.O. (1979). Preliminary survey of the fertility status of soils in Ondo State under traditional cultivation. Ife Journal of Agriculture 1: 134 -139

[7] Aduayi, E.A. 1980. Effects of Ammonium sulphate fertilization on soil chemical composition, fruit yield and nutrient content of okra. Ife Journal of Agriculture. 2. 16-34

[8] Aduayi, E.A. 1981. Micronutrient concentration of okra leaves and fruits as influenced by nitrogen fertilization. Ife Journal of Agriculture. 3. 1-7
[9] Akanbi, O.S.O., Famaye, A.O., Ojeniyi, S.O., Nduka, B.A., Taiwo, N., Olasupo, F.O., Azeez, O.M., Edibo, G.O. and Gbemisola, D.O. 2013. Growth response of cashew seedlings to applied organic fertilizers of animal and plant origin on a degraded soil in Ibadan, Southwest, Nigeria. International Research Journal of Agricultural Science and Soil Science. 3(3), $93-98$

[10] Akanbi, O.S.O., Famaye, A.O., Ipinmoroti, R.R., Ibiremo, S.O., Ojeniyi, S.O., Taiwo, N., Adejobi, K.B., Ojewole, E.O. and Oyewusi, I.K. 2012. Evaluation of sole and combined Effects of NPK fertilizer, cocoa fruit husk and oil palm bunch ash on the growth and dry matter yield of cocoa. International Journal of Applied Research and Technology 1, 172 - 177

[11] Akinrinde, E.A. and Obigbesan, G.O (2000): Evaluation of fertility status of selected soil for crop production in five ecological zones of Nigeria. Proceeding 26th Annual Conference of Soil Science Society of Nigeria, Ibadan. pp 279-288.

[12] Araki, S.I993: Effect of soil organic matter and soil fertility of the Chiteme slash and burn practice used in northern Zambia, In Mulongoy, K. and Merck, K. (Editors) soil organic matter dynamics and susceptibility of tropical agriculture Wiley Sayce, UK. 367-378.

[13] Awe, O.A; Abdulsalam, R.A. and Ogunsola, O.A. 2006: Effect of NPK 20-10-10 Fertilizer on the Pod Yield and Root Growth of Okra in the Humid Tropics. Proceedings of the $31^{\text {st }}$ Conference of the Soil Science Society of Nigeria. Zaria $13^{\text {th }}$ $-17^{\text {th }}$, November. $275-279$

[14] Ayeni L. S., Adetunji M. T., Ojeniyi S. O., Ewulo S. And Adeyemo A. J. 2008. Comparative and Cumulative Effect of Cocoa Pod Husk and Poultry Manure on Soil and Nutrient Contents and Maize Yield. American- Eurasian Journal of Sustainable Agriculture 2 (1): 92-97

[15] Christo, E. I. and Onuh, M. O. 2005. Influence of Plant Spacing on the Growth and Yield of Okra (Abelmoschus esculentus (L) Moench). Proceedings of the 39th Conference of the Agricultural Society of Nigeria (ASN) held at Benin, 9th - 13th October, Pp $51-53$.

[16] Ewulo, B.S., Babadele, O.O. and Ojeniyi S.O. 2009: Sawdust ash and Ammonium nitrate Effects on Soil and Plant Nutrient Contents and Yield of Tomato. American-Eurasian Journal of Sustainable Agriculture. 3(1), 88 - 92

[17] Folorunsho, O. O. 1999. Use of plant residue for improving soil fertility and yield of Okra and Amaranthus. Ph.D Thesis. Federal University of Technology, Akure.

[18] Folorunso, D.O. and Ofuya, T.I. 2005. Occurrence and abundance of Podagrica beetles in arable crop fields in a rainforest area of Nigeria. Proceedings of the $1^{\text {st }}$ Annual Conference on Developments in Agriculture and Biological Sciences, 27 ${ }^{\text {th }}$ April, 2005. School of Agriculture and Agricultural Technology, Federal University of Technology, Akure, Nigeria. pp 9 - 11

[19] Igwillo, N (1998): Yield of yam tubers grown from Minisetts, in relation to height of stakes and intercropping with okra (Abelmoschus esculentus (L) Moench) in the Rain Forest Zone of Nigeria. Niger Agricultural Journal 29: 95 - 105

[20] IITA (1979). International Institute of Tropical Agriculture. Manual of plant and soil analysis series no $1.57 \mathrm{pp}$ 
[21] Moyin-Jesu E.I. (2007): Use of plant residues for improving soil fertility, pod nutrients, root growth and pod weight of okra (Abelmoschus esculentus L). Biosource Technology 98 (2007) 2057 - 2064

[22] Nelson, D. W. and Sommer, L. E.(1982). Total C and organic matter in Methods of soil Analysis. Part 2. Chemical and Microbiological Properties. Winscosin A. L (Ed). $2^{\text {nd }}$ Edition ASA and SSSA. Madison WI.pp 539-579

[23] Nottidge, D.O., Ojeniyi, S.O., Asawalam, D.O. 2007. Effects of different levels of wood ash on nutrient contents of maize and grain yield in an acid ultisol of southwest Nigeria. Nigeria Journal of Soil Science 17, $98-103$.

[24] Odedina, S.A.; Odedina, J.N.; Ayeni, S.O., Arowojolu, S.A., Adeyeye, S.D. and Ojeniyi, S.O. 2003. Effects of types of Ash on soil fertility nutrient availability and yield of tomato and pepper. Nigeria Journal of Soil Science. 13. 61- 67

[25] Ojeniyi, S.O. and Adejobi, K.B. 2002. Effects of ash and goat dung manure on leaf Nutrient composition, growth and yield of amaranthus. The Nigeria Agricultural Journal 33, 46-57

[26] Ojeniyi, S.O; Adetoro, A.O. and Odedina, S.A. 1999. Effects of wood ash on Soil fertility nutrient content and yield of okra. Paper presented at Horticultural Society of Nigeria Conference, Port Harcourt.

[27] Ojeniyi, S. O. 1998. Use of ash for soil fertility and crop yield improvement Paper presented at 24 ' Conference of Soil-Science Society of Nigeria. Bauchi.

[28] Oladejo, B.T. and Ojeniyi, S.O. 1998: Effect of wood ash on soil nutrient content and maize. Paper presented at the $29^{\text {th }}$ Conference of Soil Science Society of Nigeria, Bauchi
[29] Omogoye, A. M. and Abdulraheem M. I. (2016). Soil properties and Performance of Sorghum (Sorghum bicolor L Moench) in response to Sole and Combined Applications of NPK, Cocoa Pod Husk and Cocoa Pod Ash Manures. Paper presented at the $40^{\text {th }}$ Conference of the Soil Science Society of Nigeria held at University of Calabar, Calabar. $14^{\text {th }}-18^{\text {th }}$ March.

[30] Omogoye, A. M. 2015. Efficacy of NPK and Cow Dung Combinations on Performance of Chilli Pepper (Capiscum annuum L) and their Influence on Soil Properties. IOSR Journal of Agriculture and Veterinary Science 8(7), 31-35. Retreived from http://www.iosrjournals.org

[31] Owolabi, A.O., Ojeniyi, S.O., Amodu, A.O. and Hazzan, K. 2003b. Response of cowpea, okra and tomato to sawdust and manure. Moor Journal of Agricultural Research. 4(2), 178 $-182$

[32] Qhureshi, Z. 2007. Breeding Investigation in Bhendi (Albemoshus esculentus L. Moench). Master Thesis. University of Agricultural Sciences, GKVK Uiversity, Bangalore

[33] Sharland, R.W. 1997. Understanding traditional perception of wood ash. A means of communicating soil fertility. ILEIA Newsletter 13 (3), 28-29.

[34] Tel, D.A. and Hagarty, M. (1984): Soil and Plant Analysis. IITA/University of Guelph. 277pp

[35] Udoh, D. J., Ndon, B. A., Asuquo, P. E. and Ndaeyo, N. U. 2005. Crop Production Techniques for the Tropics. Concept Publisher, Lagos, Nigeria. Pp 223-247.

[36] Van Reuler and Janssen, 1996: Efficient use of nutrients: an art of balancing plant nutrient. Field Crop Research. 